\title{
Rethinking Westernization in Destination: Tourists' Perception of a Touristic City
}

\author{
Niranjan Devkota \\ Research Management Cell, Quest International College, Pokhara University, Gwarko, Lalitpur, Nepal \\ Udaya Raj Paudel \\ Quest International College, Pokhara University, Gwarko, Lalitpur, Nepal \\ Iveta Hamarneh \\ University of Business in Prague, Czech Republic \\ Udbodh Bhandari \\ Quest International College, Pokhara University, Gwarko, Lalitpur, Nepal
}

Received: 22 February 2021. Revision received: 10 June 2021. Accepted: 16 November 2021

\begin{abstract}
The impacts of westernization are increasing globally in the tourism entrepreneurship practices. Understanding it contributes to the growth and sustainability of the business even in local touristic cities. This paper aims to judge tourists' perception of westernization about one of the most important touristic cities - Pokhara, Nepal. Purposive sampling was used to collect responses from 248 tourists in Pokhara, which included both open and closed-ended questionnaires. In order to understand the perception of tourists and check the determinants about the prevalence of westernization among tourists, the cross-sectional descriptive study has been used, and Logit Regression Model is applied. The study reveals that $78.22 \%$ of the respondents find westernization has influenced tourism entrepreneurship up to a certain extent in Pokhara. Similarly, a majority $(89.11 \%)$ of tourists reveal that they expect and enjoy local culture than their own culture in tourism destinations, where $95.56 \%$ of the tourists suggest preserving the local culture for the sustainability of tourism business in Pokhara. Results from the Ordered Logistic model show that westernization, problems faced in destination, the similarity of destination as per their expectation and level of tourists' existence at destination play significant roles in their preferences to visit touristic destinations. This study indicates that the first two reduce tourists' preferences while the latter two stimulate their preferences to visit Pokhara, Nepal. Therefore, entrepreneurs in Pokhara should identify, conserve, encourage, and maintain local socio-cultural traditions to have long-term tourism prosperity and development.
\end{abstract}

Key Words: Westernization, Entrepreneurship, Tourist's Perception, Touristic City, Nepal

JEL Classification: L84, N35, Z32

Reference: Devkota, N., Paudel, U.R., Hamarneh, I., Bhandari, U. (2021). Rethinking Westernization in Destination: Tourists' Perception of a Touristic City. Journal of Tourism and Services, 23(12), 1-25. doi: 10.29036/jots.v12i23.261

\section{Introduction}

Tourists have a variety of preferences based on their personal interests and destination (Otoo et al., 2020; Liao \& Chuang, 2020 and Grilli et al., 2021). Franklin and Crang (2001) mentioned that touristic culture encompasses visiting and exploring new places rather than just traveling physically, and Tan et al. 


\section{JOURNAL OF TOURISM AND SERVICES}

Issue 23, volume 12, ISSN 1804-5650 (Online)

www.jots.cz

(2013) suggest relaxers, sensation-seekers, and existentialists are some of the terms given to tourists. On a similar note, Nyaupane et al. (2016), Ključnikov et al. (2020a) and Civelek et al. (2021a) urged the importance of the economic growth of underdeveloped, mountainous regions. Nyaupane et al. (2016) stated the fact that mountainous regions inhabited by minority ethnic tribes which arose from these communities' inability to carry out their business of cash crops and other goods in city areas due to high competition(Fayos-Sola\& Gee, 1997; Adedoyin et al., 2021), and Briedenhann \& Wickens (2004) and Gantait et al. (2021) significantly asserted that for the micro-level upliftment of the social and economic aspects of the people of these communities many Asian countries have started to promote and develop tourism in these areas. Such development of tourism and its impact in these countries can be analyzed by the ratio of tourists to the population of the countries that is evidenced by an example of Latin American countries, such as in Brazil or Panama, Uruguay and Costa Rica, where relative impact of tourism can clearly be witnessed on local society (Walker et al., 2004). Likewise, tourists are seen as playing crucial role in the co-creation of destinations (Iglesias-Sánchez et al., 2020). Su et al. (2005), Pearce et al. (2015) and Domi et al. (2019) have justified and asserted that tourism as a socio-cultural and economic event relating to both guest-host is closely concerned with tourists' motivations and behaviors. In this sense, how the cultural elements are important for the preference and satisfaction of tourists has been revealed by Tan et al. (2016) who have pragmatically focused on the re-invention of traditional cultural tourism in order to fulfill the needs of tourist with a more meaningful experience.

It is noteworthy that tourists' preferences may be of various, which Franklin \& Crang (2001) exemplify that in a peasant village, seeing wealthy Americans or Germans can cause a lot of excitement. In favor of tourists' satisfaction and preferences, Irandu (2004) asserted that a certain culture after becoming a tourism resource should be preserved for tourists' observation all the time. If local government initiates tourism development activities involving local peoples and related stakeholders then it would be helpful to develop the destination more significantly (Choi and Murray, 2010; Çelik, 2019). Moreover, governments' support for businesses increase their entrepreneurial posture (Civelek et al., 2021b; Civelek et al., 2021c; Ključnikov et al., 2019; Ključnikov et al., 2021), thus, local economic development might also be achieved with these initiatives. Regarding Westernization, Enato (2018) has mentioned that Westernization, also known as Europeanization or occidentalization, is the process by which societies come under the influence of Western culture in sectors such as industry, technology, law, politics, economics, lifestyle, diet, clothing, language, alphabet, religion, philosophy, and values. Dai (2005) mentioned that in Turkey, the impact of westernization on the character of the state and society, which had traditionally been influenced by Islam, was perceived as a more serious issue than the West itself. Similarly, Afigbo (2005) stated that Westernization brought about cultural clashes and unprecedented changes in Esan society of Nigeria, owing largely to the imposition of Western education, economic forces, political structures, and ideas. In contrary to the critical appreciation of Westernization, Dai (2005) now mantained that in recent years, Turkish Islamists have abandoned their traditional antiwestern stance and engaged in a process of "rethinking" the West, westernization, and western political values. The Himalayan region, Nepal's unparalleled geographical position, blended with its natural beauty and cultural heritage sites has always encouraged explorers, trekkers, climbers, and tourists of various nature from around the globe (Nepal, 2000, 2020). Himalayas of Nepal were scaled by western mountaineers from 1949 (Nepal, 2000). However, mainly after the advent of democracy in South Asia in 1950s, the flow of tourists began rapidly. The record of tourist arrival in Nepal was commenced when the first tourism statistics of Nepal started (Stevens, 1988). Tourist numbers soared in the 1960s and 1970s, and after a slow start in the late 1950s, contemporary international tourism became a governmentsupported industry that, by the late 1970s, had become Nepal's primary source of foreign exchange (Devkota et al., 2020a).

Furthermore, the record shows that Nepal received 1000000 visitors in 2018, up from 2056 in 1958, 10000 in 1966 and 100000 in 1976 (Nepal Tourism Statistics, 2018). In addition, Sharma (2012) asserted that the tourism market in Nepal can be divided into three categories: volume-based, value- 


\section{JOURNAL OF TOURISM AND SERVICES}

Issue 23, volume 12, ISSN 1804-5650 (Online)

www.jots.cz

based, and emerging market-based segments, which include nations such as India, U.S.A., U. K., Japan, European nations, Australia, New Zealand, Southeast Asia, Scandinavia, China, South Asia, and Russia. Out of the total market share, Nepal accounts $45 \%$ value-based tourism. Similarly, as the tourist flow has increased in Nepal the tourism sector has also started flourishing resulting in expansion of hotels and hospitality sector. With the opening of The Hotel Royal in 1951, Boris Nikolayevich Lissanevitch, a Russian hotelier, laid the foundation for Nepal's contemporary hospitality industry. "We currently have nearly 1,000 high-quality hotels, 23,000 suites, and over 35,000 beds," he said (Sharma, 2017). Moreover, nature, adventure and culture are three major factors that highlights comparative advantage of Nepalese tourism (Sharma, 2012; Devkota et al., 2021).

However, the preference of tourists to visit Nepal is not common (Devkota et al., 2020a). Hundreds of thousands of upper- and upper-middle-class Americans, including merchants, visitors, rich women, cultural critics, politicians, and other well-off Americans, traveled Europe between 1890 and the outbreak of World War II cultivated their personal and professional lives (Endy, 1998). Americans' travel, especially after 1950s, in Nepal too, replicated such features. Further, Carter (1998) mentioned European liked hiking to make their travel as leisure travel and asserted that European perception to travel to Asian destinations stemmed from alien culture of Asia, but such alien culture didn't remain last for them as long as they gained experience traveling there. In this sense, the situation resembled with the European's travel to many destinations of Nepal too. Moreover, Chan (2006) argued that even during the 1997 Asian economic crisis, Asian tourists, particularly Chinese tourists, began to emerge with filling the regional space, despite mass tourism being primarily a Western phenomenon prior to the 1980s. The flood of Chinese tourists even reached Nepalese destinations for religious and other purposes. Furthermore, other nationals from different countries of Western and Non-Western origin are visiting different destinations of Nepal since she was opened to foreigners after 1950s (Devkota et al., 2020b).

Now, the important issue is that whether the tourists' perspective who visits Nepal supports the claim of preferring westernization or not is the study of the research (Devkota et al., 2021). Do the tourists witness westernization in the destinations of Nepal? Have the tourists influenced with their own cultural aspects in the destinations they have visited in Nepal? If yes, have they influenced in the matter of food, accommodation and socio-cultural elements? To clearly identify the tourists' perspectives on Westernization in Nepal, a thorough study is required. Such study has not been conducted before. So, the research gap is recognized Thus, this study aims to fulfill tourists' perception on Westernization in touristic city of Nepal. The study will have a considerable contribution in future research on the impact of westernization in touristic city of developing societies.

Regarding the remaining part of the paper, section two includes Socio-cultural aspects on tourists' movements and Socio-economic consequences of tourism under the title of Literature Review. Section three describes Study designing and data collection, Theoretical framework, Empirical framework, Data analysis, and Description of the study area under the title of Method. Section four covers the Result, including Socio-cultural characteristics of the respondents; Tourist's preference in visiting Pokhara, Nepal; Tourist view on Cultural Variation in Nepal; Tourists' viewpoint on tourism entrepreneurship in Pokhara; Tourist expectation in Nepal; Tourists' preference index; Ordered logistic regression analysis. Section five is Discussion and section six covers Conclusion.

\section{Literature Review}

\subsection{Socio-cultural Aspects on Tourists' Movements}

Tourism is the result of the movement of millions of people, which promotes a sense of highly diverse activities, prospects, and approaches related to this industry (Ghanem, 2017; Devkota et al., 2020b). It has indeed developed into a modern socioeconomic force around the globe today (Ranasinghe, 2014). Tourism is now seen as a viable means of achieving economic development and social reform in 


\section{JOURNAL OF TOURISM AND SERVICES}

Issue 23, volume 12, ISSN 1804-5650 (Online)

www.jots.cz

developing countries (e.g. Navickas et al., 2021). Tourism's rapid growth has resulted in both challenges and benefits for destination countries (Ranasinghe, 2014).

People who intend to travel different regions carrying different cultural background and show their excitement to explore new areas are usually called tourist. Tourists are people from various regions and cultures who are always interested in learning about the places they visit. This is commonly referred to as a tourism benefit, and it can be described in terms of friendship, learning from one another, better cross - cultural understanding, and social development. Tourists want to identify the social life of the desired location, while the native people try to emulate the tourists' way of life (Devkota et al., 2020a; 2020b; 2021).

The movement of domestic and international visitors has an impact on society and culture, either directly or indirectly. Tourism can benefit a destination country economically (Mira et al., 2018), but it also has long-term consequences that improper management and planning can endanger society (Robert et al, 2009; Ranasinghe, 2014). It has left an indelible mark on the socio-cultural and socioeconomic environment. During their visit, tourists expect to explore local culture. Cultural values have become more significant as a result of tourism (Mura and Kajzar, 2019). Traditional customs and hospitality can be regarded as strong medium to attract tourists. Tourism changes the behavior of local resident (Domi et al., 2019). In this sense, tourism is a social invasion. Any unexpected movement of tourists from one area to another has an impact on the host culture by impeding on the original way of life and social behavior when the tourist interacts with the place and people he or she visits, resulting in a social exchange. As a result, the protection of culture and the growth of tourism can be seen as competing elements to some degree (Gavurova et al. 2021). According to Anstrand (2006) the socio-cultural variables influenced by tourism are, in general, the most difficult to assess and quantify. Whereas, environmental and economical factors can be measured objectively, socio-cultural impacts are often qualitative and subjective (Ånstrand, 2006). One of the drawbacks of tourism growth, according to some scholars, is socio-cultural change. However, any form of economic growth would, by definition, have ramifications for the host population's social and cultural aspects (Ånstrand, 2006).

\subsection{Socio-economic consequences of tourism}

According to Doğan (1989) and Nepal (2000) despite the considerable and appealing economic benefits of increased tourist traffic, various negative consequences on socioeconomic and environmental factors like sexual violence, murder, theft, deterioration of native customs and values cannot be overstated. In this regard, Kumaravadivelu (2008) with the perception of westernization in tourism heterogeneity is found to be generally correlated with it, however; according to Pieterse (2010) and Uslu, Alagöz \& Güneş (2020) tourism has been shown to have both homogenizing and heterogeneity effects in local communities. Now, Dogan's (1989) argument is frequently asserted the perception is that under the influence of tourism, the host countries' traditions are undermined. Hung et al. (2017) mentioned that and even the over-commercialization of religious sites, like the Shaolin Monastery of China, where the multitude of tourists visit there annually, shows the clear and apparent impact of tourism. Again, according to Scholte (2005); Light (2001); Tong \& Cheung (2011); Mura and Kajzar (2019) tourism has made a wide range of cultural influences on younger generations, and tourism is viewed as a significant event in modernization which has been shown to have a major influence on cultural identities of young people. In this regard, Kenya can be taken as an example, how westernization can impact tourism destinations. According to Irandu (2004), after Kenya became Africa's most popular tourist destination in the 1970s, it served as a lesson to other developing- world tourism destination reflecting how westernization has impacted their local communities like Maasai, serving as a lesson to other developingworld tourism destinations (Van der Schyff et al., 2019). Loss of cultural integrity, environmental devastation, and inflation are all negative effects of tourism, as evidenced in a country like Nepal, where the culture and social structure are still traditional and vulnerable to any negative impact from tourism, and adaptation of such intact tradition/culture and westernization can be attributed to the cultural emigration 


\section{JOURNAL OF TOURISM AND SERVICES}

Issue 23, volume 12, ISSN 1804-5650 (Online)

www.jots.cz

in Nepal (Sati, 2021). In response to these kinds of western influence, Dogan (1989) and Uslu, Alagöz \& Güneş (2020) explored in detail how prominent members of the local community disapprove of changes brought about by tourism, and how this reaction contributes to the avoidance of contact with foreigners; conservation; the revival of cultural customs, local dialects, and customs, all of which are related to the issue of tourism promotion and maintain the livelihood of such communities. Buck's (1978) research explored how a religious and traditional society maintained a barrier between locals and tourists by stressing the value of tourists showing reverence for local and traditional existence, resulting in the preservation of traditional culture and dignity while also providing economic benefits to the community from tourism. In addition, Pearce (1982) discovered that tourism has helped to save heritage buildings in England. Similarly, Blomstrom et al (1978) have further supported the revelation of old traditional culture being preserved and promoted that development of tourism in Panama has created an atmosphere to establish schools for developing traditional arts and training artists leading to the revival of a forgotten and dying culture. However, the adaptation of Western culture and standardization in tourism has contributed to a common service in tourism and resulted in lack of local standards, which have created negative impacts on the climate, culture, and social norms (Peric, 2005).

\section{Methods}

\subsection{Study Designing and Data Collection Research design}

According to Paudel et al. (2018); Paudel \& Devkota (2018); Devkota et al. (2020a; 2020b) both primary and secondary data are used in this study with a cross-sectional explanatory socio-economic evaluation design. For the exploration of tourists' perceptions on the situation of tourism and Westernization in Pokhara, primary data are collected from Pokhara using organized questionnaire surveys, and secondary data are acquired from various published sources related to tourism, like records of Nepal Tourism Statistics, Economic Survey, UNWTO, Ministry of Culture, Tourism and Civil Aviation (MOCTCA). This study reveals, with the considerable use of both qualitative and quantitative aspects, tourists' perception in the touristic city of Nepal-Pokhara. The research team met with many tourist experts, people who work in tourism agencies, officials from the Nepal Tourism Board (NTB) and MOCTCA, and staff from the Trekking Agencies Association of Nepal (TAAN) and the Hotel Association of Nepal (HAN) to develop a solid methodological foundation for the study. Their suggestions, remarks, comments, and recommendations were valued by the research team in the development of the questionnaire. With the consultation of key informants and previous literature, structured questionnaire was developed. The response was collected from 248 tourists in Pokhara with the help of the purposive sampling method which included both open and closed-ended questionnaires. Further for analyzing the data Ms-Excel and STATA were used.

\section{Study setting and designing}

Tourists' perceptions of the tourism situation and westernization in Pokhara were gathered through interviews and a fully organized, open-ended questionnaire. Slovin's formula as mentioned by Rai et al. (2019) was used to select the number of tourists as:

$$
n=\frac{N}{1+\left(1+N e^{2}\right)} \ldots \ldots \ldots \ldots \ldots \ldots \text { (7) }
$$

The total population is $\mathrm{N}$, and the margin of error is e. The researchers used a $95 \%$ confidence level $(e=0.05)$ and a 10\% non-response error in their estimation. According to the calculations, the total sample size should be $361+36=397$. A total of 248 tourists were interviewed, this study covers interviewing from the tourists of different countries. In short, this research includes all kinds of visitors to Pokhara, 


\section{JOURNAL OF TOURISM AND SERVICES}

Issue 23, volume 12, ISSN 1804-5650 (Online)

www.jots.cz

regardless of their country of origin, gender, or socioeconomic status. The questionnaire was formulated after consultation with experts and tourism entrepreneurs in Kathmandu valley. Further, a pilot survey was conducted among 30 tourists in Thamel, a tourist city of Kathmandu valley. The final survey was conducted in Pokhara in 2019 after providing three days training to enumerators to aid in the research process.

\subsection{Theoretical Framework}

The perspectives of many scholars and theorists on tourism entrepreneurship have long been known. Tourism entrepreneurship has been affected in various ways by a variety of cultural, social, political, and environmental influences, and the theories developed for entrepreneurial activities have influenced a variety of variables. Pierre Bourdieu's Practice Theory (1972), Butler's Tourism Region Life Cycle Plan (1980), Edward Freeman's Stakeholders Theory (1984), and John Urry's Tourist's Gaze are some of the theoretical approaches to tourism (1992). According to Bueger \& Stockbruegger (2017); Johannesson et al. (2014) Actor- network theory originated as a distinct methodology in the late 1970s and early 1980s, in response to modern technological interest in global politics, as well as stronger interdisciplinarity between international relations (IR) and science and technology studies (STS), which later highlighted (Action, Network, and Theory) three major components associated with ANT. In this sense, , Law (1999), initiator of actor- network theory, stated that the theory can be viewed as thesemiotics of materiality. Researchers have gradually translated and conducted the theories for tourism studies (Van der Duim et al.,2013), and they also argue that actor- network theory aids in restructuring study in the field of tourism amenities, spots, destinations, and also contributing in the field of economy, sustainability, and tourist engagement in various dimensions of activities.

When it comes to tourism, Johannesson (2005) argued that places are formed and maintained through the movement of heterogeneous factors such as human, money, knowledge, objects, and brands, which are all acquired and generally observed through the interconnection between the individuals concerned. Johannesson et al. (2014) also mentioned that without human interactions tourism will not last for a longer period. Also, tourists in Pokhara stated that various actors like heritage sites, government officials, hotels, tourism agencies can also help in developing networks and relationships as revealed from this study. In another significant approach, Practice Theory can also discern tourist activities and their various dimension. In this context, Bourdieu (1977) has stated that practices are not the result of individual attitudes, thought, or rational calculations, but rather of social theory and practice rooted in a complicated system of conceptual interactions between social actors. Anthony Giddens and Pierre Bourdieu are the pioneers of practice theory, according to Lamers et al. (2017), who introduced the notion of agency-structure relations as one of the core topics of social theory and the asserted that Bourdieu and Giddens have visualized entrepreneurship as a socially embedded process linked to the entrepreneur's position in the structure of power relations, which, in turn, affects touristic movement and activities in destination, has been further consolidated by De Clercqe \& Voronov's argument (2009).

Lamers et al. (2017) state that tourism research can benefit from practice theories in three ways: by conducting an in-depth study of the importance of tourism; evaluating changes in the field of tourism and unleashing the facts regarding tourism practice as indicated by tourism activities like touring, excursions, mountain climbing, rafting, bungy and paragliding, and various other entertainment forms while traveling. We investigated tourists' attitudes to tourism practices in the above-mentioned activities, as well as the government's position (as tourism- related activities) in the development and enhancement of tourism entrepreneurship in Pokhara.

In another theoretical underpinning, the tourism life cycle theory of Butler (1980) states that depending on the destination entrepreneur's distinct attributes, present context, the development phase of a particular destination, and impact of socio-cultural factors, entrepreneurship takes on various types at different phases of the lifecycle. Furthermore, life cycle theory is expressed in a number of variants depending on its relationship to a particular business field or entrepreneurial sector. Generally, Product 


\section{JOURNAL OF TOURISM AND SERVICES}

Issue 23, volume 12, ISSN 1804-5650 (Online)

www.jots.cz

life cycle theory focuses on every kind of product including tourism- related products which comprise four phases namely; introduction; growth; maturity; and decline which further can be classified into six stages (Kozak \& Martin, 2012). In terms of behavioral aspects, investment, promotion, public-private collaboration, government initiatives, authentic socio-cultural setting, favorable climate, the development and growth of tourism entrepreneurship, and tourism activities in Pokhara can be clearly understood with the help of life cycle theory and some of its variants.

Now, stakeholder theory can be used to evaluate and explain the issue of tourism entrepreneurship and the role of government in its promotion in a much broader context. In this regard, according to Law et al. (2015), the identification and distinction of involved actors, as well as their contribution to the destination's success, are the subjects of stakeholder theory. on a similar note, organizational structures, personality of employees, and organizational strategies are the factors that influence identities that are tended to be perceived by stakeholders which impacts tourism management (Nicolaides, 2015). According to Law et al. (2015), politicians are significant stakeholders who are viewed, known, and in a better position to decide and influence over individuals or groups of tourism sector stakeholders and holds the monopoly on setting goals, which considerably determine the other stakeholder's decision to conduct their business, where tourists are the prominent stakeholders to be affected by such decisions. This also means that politicians exert major power in decision- making andsetting process. Therefore, tourists in Pokhara are seeking such initiation in policie formulation from the government that would enhance tourism in Pokhara. Urry (1992) opined four major ways for societies to interact with the physical environment: land stewardship; exploitation of land or other resources; conscientization to treat the environment as an object of scientific investigation; and visual consumption of the environment. In this context, visual consumption is treated as a tourist's gaze, which is substantially supported and preceded by other three ways. Using John Urry's ideas from his most influential literature "Tourist Gaze" Chan (2006) explained how tourists perform a "rite of passage" that involves "getting away" from everyday life together with visual signs that satisfy tourists' eagerness to observe destinations, objects, and people while traveling. Likewise, Crang (1997) also saw the work of John Urry (1990) and Gillian Rose (1993) as contributing to the formation of the looking subject in geography, with the importance of universalization of the tourist gaze, which denotes and constructs all kinds of places as its objects, is emphasized in Urry's study.

\subsection{Empirical Framework \\ Tourism Preferences Index}

This study aims to assess tourists' preferences by asking respondents five yes or no questions about food, lodging, hotel setup, art and culture, and dance and music. The goal is to determine how aware an individual tourist is in his preferences for local values and culture when visiting various touristic cities. As a result, the touristic preference for local culture was measured using five dummy-based indexes, one for each argued response and zero for the rest. This gives a theoretical range of 0 to 5 for the dummybased index. The preferences are high if they score 2 and less with $t 0$. The score range has been classified as following (Devkota and Phuyal, 2018): If the tourists obtained less value (i.e. $Y=$ 0 , If Scale Score $<50 \%$ ) they do not prefer local culture while if theyobtained $Y=1$, If $50 \%<$ Scale Score $<75 \%$ and $Y=2$, If Scale Score $>75 \%$ above the tourists tend to prefer high local cultural set up in the destination. Tourist preferences are the study's dependent variable, which is based on this preferences index. A special form of the logit model called ordered logistic regression, is needed because their preference levels range from 0 to 2 .

\section{Ordered Logit Model}

The perception of tourists in Pokhara valley can be analyzed with the help of the ordered logit model (Devkota et al., 2020b). As the result of the ordered logit should be in a certain order it is generally 


\section{JOURNAL OF TOURISM AND SERVICES}

Issue 23, volume 12, ISSN 1804-5650 (Online)

www.jots.cz

coded as 0,1, and 2 (Balarabe et al., 2018) suggesting that visitors prefer local culture to westernization. Let us assume that the ordered logit model's probability of awareness level was discussed as:

$$
\operatorname{Pr}\left(\mathrm{Y}=\mathrm{C} / \mathrm{X}_{\mathrm{i}}\right)=\mathrm{F}\left(\mathrm{X}_{\mathrm{i}} \beta\right)
$$

Where $\mathrm{Y}$ is the output obtained for the level of awareness, which is coded as $0=$ less aware, $1=$ moderately aware, and 2 = Highly aware; standard logistic cumulative function is denoted by $\mathrm{F}$, and the set of independent variables is referred to as $\mathrm{X}$. 11 independent variables were used to estimate the ordered logit model with the help of following formula for this study:

$P(Y i>j)=\frac{\exp \left(X_{i} \beta-K_{j}\right)}{1+\left[\exp \left(X_{i} \beta-K_{j}\right)\right]}, \mathrm{j}=1,2, \ldots \ldots \ldots$, M-1, which implies

$P\left(Y_{i}=1\right)=1-\frac{\exp \left(X_{i} \beta-K_{1}\right)}{1+\left[\exp \left(X_{i} \beta-K_{1}\right)\right]}$

$P\left(Y_{i}=j\right)=\frac{\exp \left(X_{i} \beta-K_{j-1}\right)}{1+\left[\exp \left(X_{i} \beta-K_{j-1}\right)\right]}-\frac{\exp \left(X_{i} \beta-K_{j}\right)}{1+\left[\exp \left(X_{i} \beta-K_{j}\right)\right]}, \mathrm{j}=2, \ldots, \mathrm{M}-1$, implying

$P\left(Y_{i}=M\right)=\frac{\exp \left(X_{i} \beta-K_{m-1}\right)}{1+\left[\exp \left(X_{i} \beta-K_{m-1}\right)\right]}$

In the case of $\mathrm{M}=2$, these equations simplify to:

$$
\begin{aligned}
& P(Y=0)=\frac{1}{1+\exp \left(Z_{i}-K_{i}\right)} \\
& P(Y=1)=\frac{1}{1+\exp \left(Z_{i}-K_{2}\right)}-\frac{1}{1+\exp \left(Z_{i}-K_{1}\right)}
\end{aligned}
$$

According to Williams (2019), to analyze the probability that the unobserved variable $\mathrm{Y}^{*}$ falls within the various threshold limits using the value of $\mathrm{Z}$ and the assumed logistic distribution of the disturbance term an ordered logit model can be used. For this study, the goal is to assess tourism perception regarding westernization in Pokhara. equation 6 as:

The depiction of empirical specification as given above in equation I can be seen below in

$Y=\alpha_{0}+\beta_{1}$ region $+\beta_{2}$ age $+\beta_{3}$ gender $+\beta_{4}$ purpose of visit $+\beta_{5}$ preference of westernization + $\beta_{6}$ level of tourism exist $+\beta_{7}$ pattern of westernization $+\beta_{8}$ duration of stay $+\beta_{9}$ total visit in Nepal $+\beta_{9}$ similar to expectation $+\beta_{11}$ problem faced $+\varepsilon$

Where,

$\mathrm{Y}=$ Awareness level $(\mathrm{i}=0,1,2)$

$\mathrm{X}=$ Independent variables (Independent variables are explained in detail in table 1)

$\varepsilon=$ Error terms

As previously stated, tourist visits to touristic cities are heavily influenced by their perceptions, newness, new culture, identity, level of tourism existence, problems, and challenges they face. To better understand tourist perceptions and awareness when visiting touristic places in Nepal, the following variables are derived as shown in table 1 the aim of this study was to use explanatory variables to interpret dependent variables. Hence, below provided hypothesis is formulated as: 


\section{JOURNAL OF TOURISM AND SERVICES}

Issue 23, volume 12, ISSN 1804-5650 (Online)

www.jots.cz

H0: Tourist preferences to visit tourist city do not matter by the presence of westernization at the destination.

Table 1 shows how explanatory variables are measured in the study along with dependent variables.

Table 1: Variables and its expectations

\begin{tabular}{|l|c|c|c|c|}
\hline VARIABLES & Mean & $\begin{array}{c}\text { Std. } \\
\text { Dev. }\end{array}$ & Explanation & $\begin{array}{c}\text { Expected } \\
\text { Sign }\end{array}$ \\
\hline Region & 0.94 & 0.25 & $1=$ Asia, $0=$ otherwise & \pm \\
\hline Age & 35.25 & 12.19 & In years & \pm \\
\hline Gender & 0.54 & 0.50 & $1=$ if male, $0=$ otherwise & \pm \\
\hline Purpose of visit & 0.71 & 0.46 & $\begin{array}{c}1=\text { if holiday and } \\
\text { pleasure; } 0=\text { otherwise }\end{array}$ & \pm \\
\hline $\begin{array}{l}\text { Preference of westernization (at } \\
\text { destination) }\end{array}$ & 0.11 & 0.31 & $1=$ Yes, $0=$ otherwise & \pm \\
\hline Level of tourism exist & 2.15 & 0.70 & Likert Scale $(1=$ Less $)$ & \pm \\
\hline Pattern of westernization & 0.78 & 0.41 & $1=$ Yes, $0=$ otherwise & \pm \\
\hline Duration of stay & 30.63 & 27.27 & In days & \pm \\
\hline Total visit in Nepal & 2.48 & 4.01 & Number in times & \pm \\
\hline Similar to expectation & 0.73 & 0.44 & $1=$ Yes, $0=$ otherwise & \pm \\
\hline Problem faced & 0.15 & 0.35 & $1=$ Yes, $0=$ otherwise & \pm \\
\hline
\end{tabular}

Source: Researchers' Calculation/ Assumption

\subsection{Data Analysis}

Both descriptive and inferential statistics were performed to identify tourists' perception of westernization in Nepalese tourist cities. In the descriptive analysis, this study demonstrated graph, figure, and percentage calculation from the data received through a questionnaire survey. That covers tourists' opinion to visit Nepal, their preference and expectation in visiting Pokhara, view of cultural variation, and observation of western culture. The descriptive analysis also demonstrates the tourists' viewpoint about tourism entrepreneurs, their status, strength, and weaknesses in terms of westernization.The tourism preference index was prepared to understand their overall satisfaction to visit Pokhara and inferential analysis was used to perform the Ordered Logistic Model as described in section 2.2. Both pre-and post-result analyses were made using STATA version 13 for statistical purposes. Logistic regression analyses have been also performed by some studies that deal with the economic development of a touristic destionation (Civelek et al., 2019; Ključnikov et al., 2020a; Ključnikov et al., 2020b).

\subsection{Description of the study area}

Tourists have been drawn to Nepal by its rich scenic beauty, which has resulted in economic contributions (Stevens, 1988). Since the first five-year development plan Pokhara has been the focal point of debate for the tourism sector's plan and policies in Nepal. Pokhara, a major tourist destination of Nepal, is situated in central Nepal, on the latitude of 28023' $\mathrm{N}$ and longitude of 83059' E, which covers a land area of 123 square kilometers and is considered an old trade route between China and India. Numerous vital geo-cultural factors, such as the Annapurna region's gateway, easy access to motor and airways, numerous cultural heritages, natural scenes, and beauty, have increasingly made Pokhara a "tourism spot". After the declaration of Pokhara as headquarter of Gandaki province by government of Nepal, the value and fame of Pokhara have further enhanced. These factors have paved the way for Pokhara's growth as a tourist destination, according to planners and policymakers (Devkota et al., 2020a; 2020b). 


\section{JOURNAL OF TOURISM AND SERVICES}

Issue 23, volume 12, ISSN 1804-5650 (Online)

www.jots.cz

As revealed by Upreti \& Upadhyaya (2013); Sharma (2013) there were a total of 573 hotels and guests house, 116 travel agencies, 81 trekking companies, 21 tourist standard restaurants, and 15 paragliding companies, as well as hundreds of handicraft centers, books stores, cyber cafes, and money changers and 6000 tourism entrepreneurs in Pokhara. Dawadi and Upadhayaya (2013) further stated that numbers of entrepreneurs and businesses are working towards promoting and enhancing tourism in Pokhara and its surroundings which has helped in attracting a large number of tourists as well. Therefore, this study can be considered viewing upon various tourism attributes regarding westernization in Pokhara.

\section{Results}

\subsection{Sociocultural Characteristics}

The average age of the respondents in the study is found 35.25 years while the minimum and maximum ages are 13 and 74 years respectively. Among the tourist found during the survey period, $54.03 \%$ respondents were males whereas, $45.96 \%$ were female respondents. Further, decomposing the ages of the observed tourist into different categories the lowest number is from 61 and above years of age $(4.03 \%)$, whereas the largest number of tourists are from the $21-30$ age group $(41.93 \%)$. The other age categories are: below 20 (4.43\%), 31-40 (29.03\%), 41-50(11.69) and of 51-60 (8.87\%) years. Collins \& Tisdell (2002) examined how age can be a significant factor, citing Becker and Lawson as the first scholars to discuss how tourist distances differ with their age and asserted that age can be a useful variable in predicting the relations between family lifecycle and age-related tourism functions. Moreover, Jönsson \& Devonish (2008) argued that tourists in the older age group prefer to travel for increasing their knowledge of local places, whereas younger people like to engage in traveling for sports.

The average duration of the stay in Nepal in 2017 is 13 days and from this study, we observed the average days of stay by tourists is 30.62 while minimum and maximum stay-period are 3 and 135 days. Our survey suggests that the average visit by tourists to Nepal is found 2.47 times with the maximum number of visits as 24 times. At the same time, the average visit of these tourists to Pokhara is 2.11 times where the maximum and the minimum number of visits is 24 and 1 times respectively. It shows Pokhara is a quite attractive place within Nepal for visit.

More than half of the tourists who have visited Nepal mentioned that their way of knowing Nepal from friends is $59.27 \%$. Besides, getting knowledge about Nepal by tourists from other different means is internet (35.8\%), travel agencies $(4.83 \%)$ where the lowest number of tourists $(1.61 \%)$ is found to arrivingin Nepal is by invitation. Still, about $15.32 \%$ of tourists are found gaining information about Nepal is by other means than mentioned above.

In terms of the regional flow of tourists to Nepal, the study observes that the largest number of tourists coming to Nepal is from Europe which is 59.67\% (male- 29.03\%, female-30.64\%), where encompassing countries are Austria, Denmark, Sweden, Russia, England, France, Finland, Czechoslovakia, Germany, Holland, Romania, Poland, Spain, Italy, Switzerland, Scotland, Belgium, Norway, Ukraine, Slovenia, Luxemburg, and Ireland. After Europe comes the American region suggesting the second largest number of tourists coming to Nepal, which is $18.54 \%$ (male- $12.5 \%$, female$6.04 \%$ ), where the comprising countries of this region are Canada, America, Mexico, Columbia. Another region from where tourists are coming in Nepal is Australia, which includes Australia and New Zealand. The figure of tourists coming from these countries shows $13.70 \%$ (male- $7.25 \%$, female- $6.45 \%$ ). The lowest number of tourists coming to Nepal is from the Asian region, which is $6.45 \%$ (male- $4.43 \%$, female-2.01\%), the comprising countries of this region are India, Japan, Thailand, and Korea.

\subsection{Tourists Preference in Visiting Pokhara, Nepal Tourists opined several reasons to visit Nepal}




\section{JOURNAL OF TOURISM AND SERVICES}

Issue 23, volume 12, ISSN 1804-5650 (Online)

www.jots.cz

Tourists express several reasons to visit Nepal and among these reasons, the most preferring one is the mountain and hill of Nepal $(23.40 \%)$. Other reasons are lovely Nepali people $(23.15 \%)$, natural beauty (19.08\%), and culture and arts (11.70\%). Besides, tourists also consider Nepali typical food (4.07\%), trekking and river (3.30\%), hospitality $(3.30 \%)$, good weather $(0.7 \%)$ for their visit to Nepal. Buddhist culture $(0.7 \%)$, beautiful tourist area $(0.2 \%)$, forest $(0.7 \%)$, Monasteries $(0.2 \%)$, lakesides $(0.2 \%)$, greetings and friendly environment $(1.78 \%)$ are also other suggestive reasons for why the tourists come to Nepal. Some of the major factors that aid tourism destinations according to Hsu et al. (2009) are Selfactualization, making new friends, proper health facilities, exploring new ideas and things, nightlife exposure and experience, proper access to transportation, foods of different cuisine, warm hospitality, good market to shop around, security, and profit aspirations.

\subsection{Tourist View on Cultural Variation in Nepal Cultural Variation in Nepal}

As tourists come from different socio-cultural backgrounds and periphery, this study tries to understand whether the county, here Nepal, is like their expectation - expectation of being similar to one's own country. Out of total respondents, $73.79 \%$ of the respondents argue for the similarities to their own country, whereas $13.70 \%$ of visitors don't see any similarity to their native country, and $6.45 \%$ and $6.04 \%$ of tourists respond to 'May Be' and ' $N o$ Idea'. Respondents compare their culture with Nepali culture in terms of similarities as given in figure 1.

Figure 1. Tourists' perception on cultural variation in Pokhara

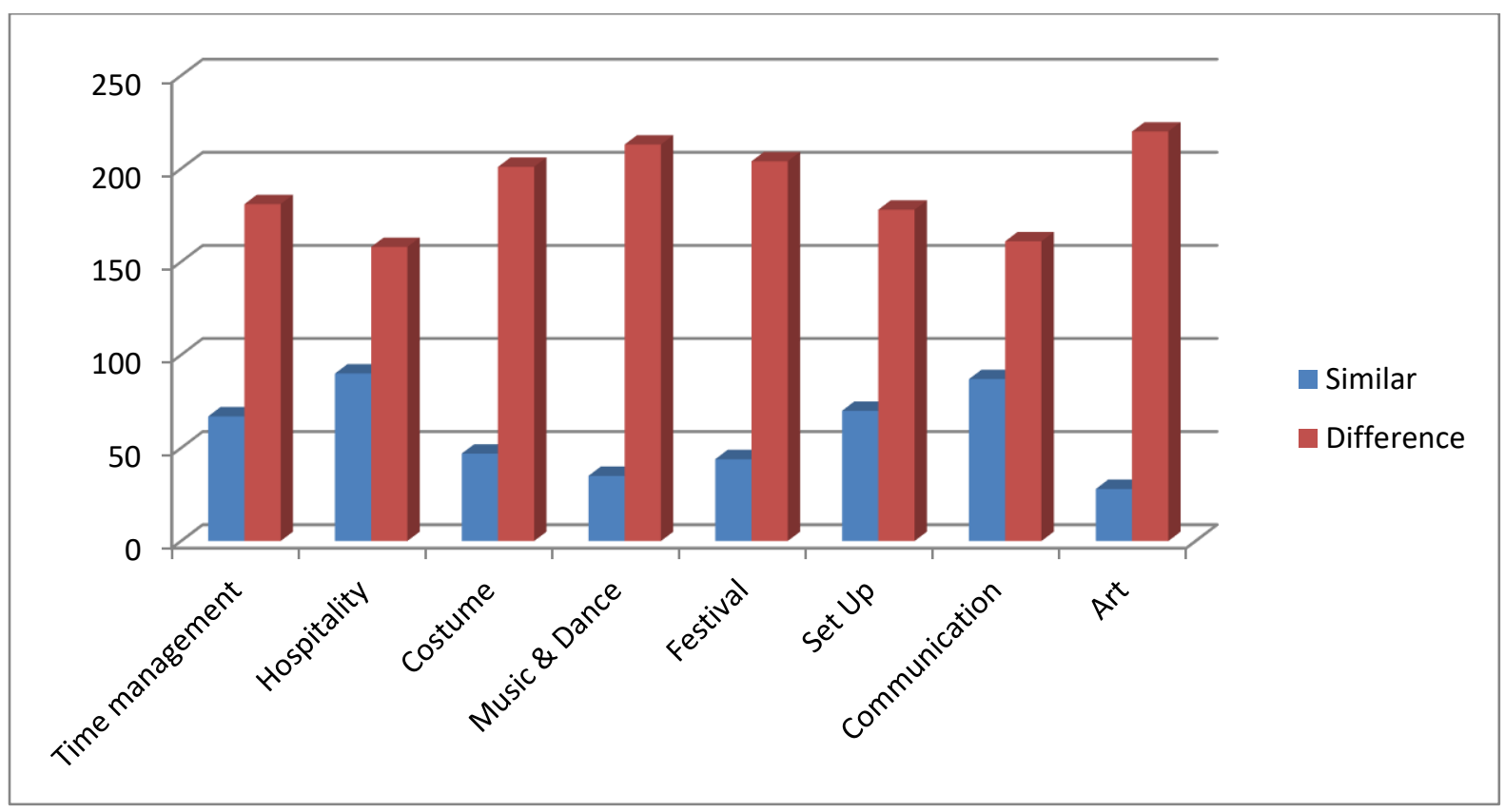

Source: own research

For the similarity option respondents' views are food $(44.35 \%)$, accommodation $(25.80 \%)$, transportation (16.53\%), hospitality (42.33\%), security (14.51\%) and others (5.64\%). Eric Amuquandoh \& Asafo-Adjei (2013) focused that understanding tourists' preference and consumption of traditional food in host country makes paramount importance, especially in the destinations of developing countries. In our research, regarding the differences of amenities of Nepal to their own country, the survey finds that $5.64 \%$ of the respondents see the difference in food. The tourists observing for the differences in 


\section{JOURNAL OF TOURISM AND SERVICES}

Issue 23, volume 12, ISSN 1804-5650 (Online)

www.jots.cz

accommodation, transportation, hospitality, security, and other status are 4.83\%, 8.87\%, 4.03\%, 3.22\%, and $3.22 \%$ respectively.

\section{Western Culture in Nepal}

$78.22 \%$ of the tourist respondents find the western pattern of the culture in Nepal, whereas $21.27 \%$ of them do not find any. In general, Mowforth and Munt (1998) asserted that globalization as a mechanism with an ever-tightening network of links cutting across national political borders and linking societies in a single, interdependent whole in a shrinking world is eroding local differences, and as Azarya (2004) stated globalization has both pros and cons for tourism. In our study, those tourists who have observed such western culture in Nepal express their view at different levels of intensity including extremely high (4.166\%), high (27.08\%), moderate (49.59\%), low $(3.62 \%)$. The level at 'Extremely Low' does not show any response. For such circumstances of surveyed response, Dogan (1989) \& Nettekoven (1979) have observed and analyzed that some groups of host societies, generally youths and educated group of third world nation tend to make an effort to abolish the traditional social structure and adopt western culture symbolized by tourism. This viewpoint is backed up by Wood (1980); Garland \& West (1985) who claimed that tourism has helped to represent the life of the elite groups of third world countries and further helped to connect people of western and third world nations. Such overwhelming attitudes and practices of individuals in host countries are responsible for the distortion of traditionalism and penetration of western values in those societies. In this research, tourists were asked whether they prefer more westernization in Nepal or not? In response to this only $10.88 \%$ of tourists express that they prefer more westernization in Nepal while $89.11 \%$ view they do not prefer it. The result further suggests that $3.70 \%$ of tourists show their level of preference over westernization as extremely high. High, moderate, low, and extremely low levels of preferences, on the other hand, have been found as $22.22 \%$, $62.96 \%, 3.70 \%$, and $3.70 \%$ correspondingly.

The study finds that $95.56 \%$ of tourist respond as they prefer the preservation of local culture while only a few tourists $(4.43 \%)$ opine they don't prefer it in the touristic city of Nepal. Among those tourists who prefer local culture, $22.78 \%$ prefer extremely high and the remaining $56.96 \%, 18.56 \%$, and $1.26 \%$ prefer a high, moderate, and low level of preservation of local culture in Nepal respectively. However, tourists do not show any response for the 'Extremely Low' level of protection of local culture.

\subsection{Tourists' Viewpoint on Tourism Entrepreneurship in Pokhara \\ Tourists' Opinion about Tourism Entrepreneurship in Nepal}

This study observes that $16.53 \%$ of tourists feel a very strong level of tourism entrepreneurship in Nepal. However, the largest number of the tourists $(53.62 \%)$ found the tourism entrepreneurship 'strong' only. Additionally, 29.03\% of the respondents view the level of entrepreneurship as moderate; while $0.40 \%$ senses entrepreneurship level as low, and the rest $0.40 \%$ observe it as very low.

\section{Entrepreneurs Role to Strengthen Tourism Development in Pokhara}

Tourists view that entrepreneurs have a pivotal role to strengthen tourism entrepreneurship in Nepal. Some of the respondents opine entrepreneurs can partake to manage socio-environmental aspects of the city. Regarding the social part of the city, tourist opine entrepreneurs can create a lovely social atmosphere for tourist that leads to a more cultural and local attraction, where for environmental milieu, respondents suggest, entrepreneurs can work for waste management and can promote the neat and clean touristic area, maintain hygiene and manage for a peaceful environment for the tourist.

Preservation of local culture, promotion of hospitality, and minimization of western culture are other important aspects as tourists opine that entrepreneurs can act for. In addition,the enhancement of the English language for easy communication with tourists along with destination and time management are also other issues that entrepreneurs can consider for the act of promotion. Likewise, respondents further opine that entrepreneurs can have an important role in improving the trekking management system and enhancement of health safety. In addition, more investment, an improvement on price and trade of food, accommodation and all other required amenities with proper development and 


\section{JOURNAL OF TOURISM AND SERVICES}

Issue 23, volume 12, ISSN 1804-5650 (Online)

www.jots.cz

management of tourist agency, enhancement of quick services and promotion of more professionalism on their business are some other crucial things that entrepreneurs of Pokhara can work for the development of tourism entrepreneurship of this region.

Tourists also opine that developing and promoting information systems about Pokhara by frequently updating tourism websites are such important parts of tourism entrepreneurship in Pokhara that entrepreneurs can manage easily which is a very fundamental aspect to appeal to foreign tourists. Further, tourists also mention that entrepreneurs can work as facilitators for promoting governmental activities on tourism development in Pokhara. They suggest government towards the development of transportation $(18.54 \%)$ and infrastructure $(4.43 \%)$, provision for the privilege of subsidies $(2.82 \%)$, and proper policy implementation $(2.41 \%)$. They also suggest for political parties' seriousness $(0.43 \%)$ towards the development of the touristic city.

\section{Problems Faced in Pokhara}

The results show that the largest number of tourists $(66.93 \%)$ have faced nothing like any sort of problems during their visit to Nepal. $7.66 \%$ of the respondents have experienced the problem of theft while registration hassle $3.24 \%$, deception $4.03 \%$, procedural complexities $13.30 \%$ are other problems faced by the tourists during their stay in Nepal. Communication is considered another difficulty respondents have experienced during their stay. The study shows $14.51 \%$ of the respondents observe communication problems during their stay while $85.48 \%$ opine they didn't face any such problem.

\subsection{Tourist Expectation in Nepal \\ Reasons in lacking Pokhara as a Touristic City}

Tourists argue transportation/road (41.93\%) and infrastructure development (13.30\%) are still the major lacking to promote Pokhara as a touristic city. Besides, pollution (28.22\%) is another important barrier for promoting tourism in Pokhara. Some other respondents opine that lack of government seriousness $(10.88 \%)$, security $(1.20 \%)$, no strict rules and regulation $(1.20 \%)$, rampant corruption $(2.82 \%)$, accommodation $(3.62 \%)$, irritation from street children $(0.40 \%)$ are some other reasons that have barred Pokhara to grow it as a fully touristic destination.

A few numbers of the respondents mention low public awareness $(2.82 \%)$, lack of English communication (i.e., communication barrier, 3.62\%), low advertisement scale (1.61\%), low education $(1.20 \%)$, lack of innovative thinking $(0.40 \%)$, not clear idea about the importance of local culture $(2.82 \%)$, hygienically poor visiting area $(2.01 \%)$, poor hospitality $(1.20 \%)$ and lack of time management $(4.03 \%)$ are some other barriers to enhance Pokhara as a better tourist city.

\section{Recommendation from Tourists to Promote Touristic City in Nepal}

Tourists have given many recommendations to improve, upgrade and promote the touristic city in Nepal (Devkota et al., 2021). Out of many viewpoints, pollution control/recycling $(16.03 \%)$ is largely opined views. It is followed by hygiene $(1.78 \%)$ and removal of old vehicles $(1.52 \%)$. Further, some other tourists give their suggestions on infrastructure $(14 \%)$, road $(6.87 \%)$, and improvement of the airport $(2.54 \%)$, better transportation facilities $(2.0 \%)$ and travel enhancement $(0.2 \%)$. Few of the tourists $(18.54 \%)$ also consider governmental priority/attention, strict rules/laws, public awareness, community involvement, helping villagers, and promotion of proper roadmap for sustainable tourism development of Pokhara. Also, 7.65\% of respondents recommend advertisement of the beautiful touristic city from all possible means. Among them, online promotion for the beauty of the cultural values and heritage of Pokhara is taken as the prime importance that tourist can easily get access to search and understand the beautiful touristic view.

\section{Tourists Recommendation of Governmental Services (for Visiting Nepal and Destinations)}

In the survey, the majority of the tourists suggest the enhancement of transportation facilities $(24.59 \%)$ followed by infrastructure development (5.64\%) and traffic management (2.01\%) for the betterment of tourism development in Pokhara. Besides, waste management/cleanliness (6.04\%), the 


\section{JOURNAL OF TOURISM AND SERVICES}

Issue 23, volume 12, ISSN 1804-5650 (Online)

www.jots.cz

mechanism to reduce/remove pollution (5.64\%), cleaning the plastic garbage (1.20\%), promotion of the public park and open space $(1.20 \%)$ ) are other opinions that tourists have suggested. Furthermore, tourists also recommend for tourism development (2.82\%), special care in tourism $(2.41 \%)$, quick service for immigration visa $(2.41 \%)$, government attention $(2.41 \%)$, making the availability of suitable local guides $(2.01 \%)$, facility of security/safety measures (2.01\%), establishing more tourist office $(1.20 \%)$, public care and attention $(1.20 \%)$ at the destination area for their joyful touristic stay in the destination.

\subsection{Tourists' Preference Index}

In response to preceded calculation (table 2), it is observed that about half of the respondents (48.4\%) highly prefer local values while another one-third (31\%) opine moderate preference in local entities. Only 1 tourist out of 5 (i.e. $21.4 \%$ ) prefer less local culture and values for the destination. It indicates that local culture, values that include food, accommodation, hotel set-up, art and architecture, and dance and music are still in priority of the tourists visiting new destinations. Table 2 shows the tourists' destination preferences.

Table 2. Tourists' destination preferences

\begin{tabular}{|c|c|c|c|c|c|}
\hline \multirow{2}{*}{ Variables } & \multirow{2}{*}{ Attributes } & \multicolumn{3}{|c|}{ Preferences } & \multirow{2}{*}{ Total } \\
\hline & & Less & Moderate & High & \\
\hline Tourists' preference & Overall & $53(21.4)$ & $75(30.2)$ & $120(48.4)$ & 248 \\
\hline \multirow{2}{*}{ Region } & Asian & $4(25.0)$ & $3(18.8)$ & $9(56.3)$ & 16 \\
\hline & Others & $49(21.2)$ & $72(31.0)$ & $111(47.8)$ & 232 \\
\hline \multirow{2}{*}{ Gender } & Male & $29(21.6)$ & $43(32.1)$ & $62(46.3)$ & 134 \\
\hline & Female & $24(21.1)$ & $32(28.0)$ & $58(50.9)$ & 114 \\
\hline \multirow{2}{*}{ Visit purpose } & Holiday and pleasure & $37(21.1)$ & $39(22.1)$ & $89(50.8)$ & 175 \\
\hline & Others & $16(21.9)$ & $26(35.6)$ & $31(42.5)$ & 73 \\
\hline \multirow{2}{*}{ Prefer westernization } & Yes & $10(37.0)$ & $9(33.3)$ & $8(29.7)$ & 27 \\
\hline & $\mathrm{No}$ & $43(19.4)$ & $66(29.9)$ & $112(50.7)$ & 221 \\
\hline \multirow{2}{*}{$\begin{array}{l}\text { Similar to } \\
\text { expectation }\end{array}$} & Yes & $31(16.9)$ & $60(32.8)$ & $92(50.3)$ & 183 \\
\hline & No & $22(33.8)$ & $15(23.1)$ & $28(43.1)$ & 65 \\
\hline \multirow{2}{*}{$\begin{array}{l}\text { Problem faced } \\
\text { during visit }\end{array}$} & Yes & $12(33.4)$ & $11(30.5)$ & $13(36.1)$ & 36 \\
\hline & No & $41(19.3)$ & $64(30.2)$ & $107(50.5)$ & 212 \\
\hline
\end{tabular}

\subsection{Ordered Logistic Regression Analysis}

To investigate the factors that influence tourist preference in Nepal, a logistic regression model (both logit and probit regression models) was used. Using logit and probit together provides a comparison in results. Greene (2003) mentioned cross-sectional data analyses are typically plagued by two issues: heteroscedasticity in the error term and multicollinearity among explanatory variables. To deal with the issue of multicollinearity, the Collin test was used, and the VIF score for the model was found to be less than 2. In this study, for multicollinearity, Instead of using the Breusch-Pagan test, the Collin test was used because it allows for direct multicollinearity estimation after logit regression, while the Breusch-Pagan test requires OLS estimation (Devkota \& Phuyal., 2018). Likewise, we estimate BreuschPagan / Cook-Weisberg test for heteroscedasticity and found the dataset is free from heteroscedasticity (as the value is 0.0574). Similarly, the Pseudo-R2 ranges have a value of 0.06 , suggesting that the model will best fit for predicting tourism perception in Nepal which was chosen for analysis. The result is presented in table 3. 
Table 3. Determinants of tourist preferences in touristic city

\begin{tabular}{lcc}
\hline Variables & $\begin{array}{c}\text { Logit Model } \\
\text { Tourist preference index }\end{array}$ & $\begin{array}{c}\text { Probit Model } \\
\text { Tourist preference index }\end{array}$ \\
\hline Region & -0.659 & -0.348 \\
Age & $(0.556)$ & $(0.318)$ \\
Gender & 0.00882 & 0.00697 \\
& $(0.0118)$ & $(0.00716)$ \\
visit_purpose & -0.279 & -0.142 \\
prefer_westernizarion & $(0.256)$ & $(0.153)$ \\
level_of_tourism_exist & 0.286 & 0.165 \\
pattern_of_westernization & $(0.274)$ & $(0.166)$ \\
duration_of_stay & $-0.824^{* *}$ & $-0.515^{* *}$ \\
total_visit_nepal & $(0.398)$ & $(0.237)$ \\
& $0.439 * *$ & $0.242^{* *}$ \\
similar_to_expectation & $(0.189)$ & $(0.112)$ \\
& 0.220 & 0.0956 \\
problem_faced & $(0.317)$ & $(0.189)$ \\
Constant cut1 & $0.0154^{* * *}$ & $0.00946^{* * *}$ \\
Constant cut2 & $(0.00547)$ & $(0.00333)$ \\
& -0.00269 & -0.00460 \\
Observations & $(0.0439)$ & $(0.0267)$ \\
& $0.707 * *$ & $0.403^{* *}$ \\
& $(0.296)$ & $(0.174)$ \\
& $-0.897^{* *}$ & $-0.553^{* * *}$ \\
& $(0.358)$ & $(0.214)$ \\
& 0.188 & 0.129 \\
& $(0.919)$ & $(0.552)$ \\
& $1.695^{*}$ & $1.035^{*}$ \\
& $(0.924)$ & $(0.554)$ \\
& 248 & 248 \\
\hline
\end{tabular}

Standard errors in parentheses

$* * * \mathrm{p}<0.01, * * \mathrm{p}<0.05, * \mathrm{p}<0.1$

Source: own research

This research links Nepalese tourism preference concerning all variables. The result presented in Table 1 shows the preference of westernization, the existence of tourism level, duration of stay, similar to expectation and the problem faced have played statistically significant role to prefer tourist to visit Nepal. An increase in westernization and the problem faced by the tourists during their visit to the destinations help to decrease the odds of perception of tourists in Nepal. The presence of tourism, duration of stay, and comparable to expectation, on the other hand, are a statistically significant with a positive sign, suggesting that tourism preference is growing in Nepal. The odds of those tourists who prefer to visit Nepal are 2.02 times, 1.55 times and, 1.01 times higher than the tourists who do not prefer local cultural values in the touristic city.

\section{Discussion}




\section{JOURNAL OF TOURISM AND SERVICES}

Issue 23, volume 12, ISSN 1804-5650 (Online)

www.jots.cz

In the survey, both males and females participated more or less equally. In this sense, Nyaupane et al. (2006) have mentioned a woman's saying from Ghandruk (a village located on the way to Annapurna base camp) that women tourists urged women in rural areas to be on equal terms with men in any way with her further focus that women travel like men with a lot of confidence. It can symbolize and is more indicative that travel is no more male- dominated phenomenon and it suggests that females have already come out of the narrowed premise of the familial and cultural boundary of their respective countries. Further, according to Harold et al. (2001), female visitors from North America and Europe travel to underdeveloped countries in the southern hemisphere for vacations. According to Aitchison \& Reeves (1998); Zhang et al. (2008), females are reluctant to travel by an insecure attitude about their safety when traveling (Wilson \& Little, 2008). Our study found that the average length of stay in Nepal was 31 days while the average length of tourists to stay in Nepal in 2017 was 17 days (Devkota et al., 2020a), suggesting that tourists are increasingly choosing Nepal for longer stays. In this case, Nepal's (2000) statement seems to be more insightful and relevant which states that high-budget tourists make short trips with package facilities, while the majority of low-budget visitors are self-sufficient and intend for a much longer stay. Nepal can be further developed for both categories tourists and tourists' preference in arriving Nepal should be taken seriously, promoted, and managed by the government and other travel-trekking agents sustainably.

Further, regarding the regional flow of tourists to Nepal, the result of the study shows Europeans are in larger number whereas the lowest number of flows is from Asian region (i.e., including India, Japan, Thailand, and Korea. This result suggests it is more to do for making Asian tourists come to Nepal, especially for the Indian and Chinese tourists, for which geographical proximity and neighborhood of Nepal with China and India demands a strategic touristic plan from government and other tourism stakeholders to be formulated (Devkota et al., 2020b).

There could be various reasons people would want to visit Nepal but this study showcases that among different reasons major reason for tourists to visit Nepal is to explore its natural beauty in terms of mountains and hills and its beautiful geographical setup. While considering various factors that encouragetourists to visit certain places comprises of their perception, satisfaction, marketing, seasonal trends (Poria et al., 2004; Moscardo, 1996; Laws, 1998; Nuryanti, 1996; Hadwen t al., 2011). Likewise, push and pull factors as well can encourage tourists to travel (Crompton, 1979; Yuan \& McDonald, 1990) with push factors predisposing people to travel and pull factosr attracting them to a particular destination. If unexplored destinations are identified and tapped along with the overall management of already used destinations, Nepal can have forward leap with the remarkable achievement of the tourism industry.

The fact that the majority of informants perceive connections in their own country's culture and traditions with Nepal suggests that westernization has a significant impact on the tourism sector of Nepal. According to Dogan (1989), with the adoption of western ideology, even some third-world governments see tourism as a way to integrate their countries with the socio-cultural aspect of western nations and tried to develop the tourism sector as of the western world as well. On a similar note, in Nepal also amajority of tourists believe that Nepali culture is somehow modified after western culture. In contrast to their perceptions of the cultural adaptation, the majority of tourists have expressed dissatisfaction with Nepal's increasing westernization in the sector of tourism. Tourists' aversion to westernization stems from their affinity for destinations' original and typical socio-cultural settings. Manifestation of such tourists' exposition can be recommended to all three tiers of governments for their effortful initiatives for the preservation of native culture and enhancement and promotion of the Nepalese tourism industry.

Currently, tourists have reacted at various levels to the growth of entrepreneurship in Nepal, with few of them observing it to have prospered very strongly, and many tourists believing tourism entrepreneurship to have flourished intensely. The revelation of such opinion and perception from tourists has underlined the development of tourism entrepreneurship in Nepal at a remarkable level. Tourists claim that entrepreneurs are vital to the tourism sector's development. Respondents believe that entrepreneurs can have a multitude of roles, which encompasses the roles on the preservation of local 


\section{JOURNAL OF TOURISM AND SERVICES}

Issue 23, volume 12, ISSN 1804-5650 (Online)

www.jots.cz

culture and minimization of western culture; promotion of hospitality; improvement of the trekking management system; enhancement of quick services and promotion of more professionalism on their business; more investment and improvement on price and trade of food, accommodation. These suggestions and recommendations from the side of tourists can have far sight implication for the enhancement of tourism business in Pokhara that for which entrepreneurs can take substantial initiatives in coordinating with other tourism stakeholders along with all three tiers of governments (Devkota et al., 2020a). In addition, for tourists, as they opine, the development and updating of the website for the overall information related to the tourist destination and available amenities iare the important part that entrepreneurs can promote. Moreover, governments might encourage the usage of online marketing and social media channels by entrepreneurs, thus, these entrepreneurs might draw attentions of prospective customers (Civelek et al., 2020; Vavrecka et al., 2021)

While asked about problems faced by tourists in Nepal majority of tourists said they had no problems during their visit and only afew of them said they had communication issues. This scenario means that entrepreneurs and other main tourist agents in Nepal have intricately controlled and promoted the hospitality and travel industries. Tourists, on the other hand, suggest that Pokhara still needs additional transportation and infrastructure growth. Furthermore, there is still a long distance to travel along the highway of tourism entrepreneurship to make this sector of business more sustainable, touristfriendly and create the country a central and attractive destination within the Asian region.

\section{Conclusion}

This study looks at signs of westernization from the perspective of international tourists in Nepal's tourist city of Pokhara. Purposive sampling was used to collect responses from 248 tourists in Pokhara, and open and closed- ended questionnaires were used. The majority of respondents supported the preservation of local socio-cultural dimensions in the growth of tourism entrepreneurship. In this regard, Goffi, G et al. (2020) asserted that preserving the natural and cultural heritage along with the availability of local products increases the understanding and satisfaction of the quality of tourism services by the visitors. Further, Cucculelli \& Goffi (2016) contended that preserving natural and social- cultural assets affects the competitiveness of destinations in small and medium-sized Italy. Tourists urged entrepreneurs to prioritize identifying, preserving, encouraging, and sustaining their activities. The crosssectional descriptive study with a logit regression model mirrors the ample pieces of evidence of westernization in the touristic city of Nepal. Hence, this paper not only declares the impacts of westernization in Pokhara but also provides the judgments from the tourist's perspective. In a wider context, the result and findings of the research can closely be analyzed in terms of Practice Theory, tourism Region Life Cycle Plan, Stakeholders Theory, and John Urry's Tourist's Gaze Theory. Moreover, although the findings of the research have broad impications over the influence of Westernization in touristic destinations, the research has some limitations. We have made our study only in a small area of a tourist city, Pokhara, and have collected the information from 248 tourists arriving from few countries only . After all, the findings of this research would be useful very much in any of the forthcoming researches in the touristic destinations of developing societies of the world. We strongly believe that the results of this research will be resourceful in identifying and analyzing whether Westernization is inevitable and needed or preservation of local culture becomes an essential element in the destination for the promotion and sustaining of the tourism industry.

1. Rethinking westernization: The finding in this study indicates that westernization is increasing in Pokhara. When such imitation of the West becomes more prevalent, tourists will be unable to witness local socio-cultural factors, and visiting Pokhara will become less important. The main attractions in Pokhara are oriental culture and, in particular, local culture. 


\section{JOURNAL OF TOURISM AND SERVICES}

Issue 23, volume 12, ISSN 1804-5650 (Online)

www.jots.cz

2. Preservation of local socio-cultural aspects: In tourist businesses, particularly in providing services to tourists, local Gurung and Newar community cultures can be accommodated. People in the local community can be involved, protected, sustained, and uplifted in terms of social aspects. They should maintain their sense of self-identity and be proud of their own beliefs and history.

3. Developing Tourists' Hubs: According to tourist responses, Pokhara is a popular destination and they enjoyed staying there. As a result, promoting it as a tourist destination based on tourist interests is easy. The provincial government and the federal government should cooperate to establish policies that promote the province as a tourist destination. Tourists should be offered value for money as well as a systematic provision of nightlife and leisure activities.

4. Hassle- free, prompt, and quality services: Tourist guides could assist tourists in visiting Pokhara's numerous tourist attractions. Multiple registrations should be avoided when visiting tourist destinations in and around Pokhara. They should be provided with timely and high-quality facilities. The provincial government should be responsible for administering reasonable transportation costs, entry fares, and other related issues. The hotel should have excellent services and so on.

5. Infrastructure and Tourist Points Formation: According to respondents, Pokhara should establish infrastructures such as highways, town planning, business and registration areas, and building parameters. This will help to retain local socio-cultural viewpoints. Along with these developments, there are tourist attractions. Tourist points around Pokhara for longer stays are becoming increasingly relevant as the city grows.

As a result, the study suggests that only by preserving the local socio-cultural aspects will be able to develop and stabilize tourism entrepreneurship. It means we should rethink about the more copy of the western traditions for no good reasons in the name of planning and inviting tourists to Pokhara. However, to borrow Arjun Appadurai, it will be wise to "think globally and act locally". Besides, This research has uncovered an issue for further research in other touristic destinations of the developing societies of the world on whether westernization is inevitably required or the preservation of localization is realized for the promotion of tourism industries in those societies.

\section{References}

1. Adedoyin, F. F., Nathaniel, S., \& Adeleye, N. (2021). An investigation into the anthropogenic nexus among consumption of energy, tourism, and economic growth: Do economic policy uncertainties matter?. Environmental Science and Pollution Research, 28(3), 2835-2847.

2. Afigbo, A. E. (2005). Nigerian history, politics and affairs: the collected essays of Adiele Afigbo. Africa World Press

3. Aitchison, C., \& Reeves, C. (1998). Gendered (bed) spaces: The culture and commerce of women only tourism. Gendered (bed) spaces: the culture and commerce of women only tourism., 47-68.

4. Andronicou, A. (1979). Tourism in Cyprus (pp. 237-265). Oxford University Press for World Bank and UNESCO.

5. Ånstrand, M. (2006). Community-based tourism and socio-culture aspects relating to tourism: A case study of a Swedish student excursion to Babati (Tanzania). Södertörn University College, School of Life Sciences, Sweden.

6. Azarya, V. (2004). Globalization and international tourism in developing countries: Marginality as a commercial commodity. Current Sociology, 52(6), 949-967.

7. Blomstrom, R. L., \& McIntosh, R. W. (1978). The positive side of tourism development; principles for identifying and developing the cultural resource potential. In: International tourism congress, Marmaris, Turkey. Journal of the School of Business Administration, Mugala, Turkey, 1(3). 
8. Bourdieu, P. (1977). Outline of a Theory of Practice (Vol. 16), Cambridge university press.

9. Briedenhann, J., \&Wickens, E. (2004). Tourism routes as a tool for the economic development of rural areas - vibrant hope or impossible dream?. Tourism management, 25(1), 71-79.

10. Buck, R. C. (1978). Toward a synthesis in tourism theory. Annals of Tourism Research, 5(1), 110-111.

11. Bueger, C., \& Stockbruegger, J. (2017). Actor-network theory: Objects and actants, networks and narratives. In Technology and World Politics (pp. 42-59). Routledge.

12. Butler, R. W. (1980). The concept of a tourist area cycle of evolution: Implications for management of resources. Canadian Geographer/Le Géographecanadien, 24(1), 5-12.

13. Carter, S. (1998). Tourists' and travellers' social construction of Africa and Asia as risky locations. Tourism Management, 19(4), 349-358.

14. Çelik, S. (2019). Does tourism change tourist attitudes (prejudice and stereotype) towards local people?. Journal of Tourism and Services, 10(18), 35-46.

15. Chan, Y. W. (2006). Coming of age of the Chinese tourists: The emergence of non-western tourism and host-guest interactions in Vietnam's border tourism. Tourist studies, 6(3), 187213.

16. Choi, H. C., \& Murray, I. (2010). Resident attitudes toward sustainable community tourism. Journal of Sustainable Tourism, 18(4), 575-594.

17. Civelek, M., Ključnikov, A., Krajčík, V., \& Žufan, J. (2019). The Importance of Discount Rate and Trustfulness of A Local Currency for the Development of Local Tourism: Journal of Tourism and Services, 10 (19): 77-92. https://doi. org/10.29036/jots. v10i19. 117.

18. Civelek, M., Gajdka, K., Světlík, J., \& Vavrečka, V. (2020). Differences in the usage of online marketing and social media tools: evidence from Czech, Slovakian and Hungarian SMEs. Equilibrium. Quarterly Journal of Economics and Economic Policy, 15(3), 537-563. doi: 10.24136/eq.2020.024

19. Civelek, M., Ključnikov, A., Kloudová, J., \& Vozňáková, I. (2021a). Digital Local Currencies as an Alternative Digital Payment Method for Businesses to Overcome Problems of Covid19 Pandemic. Polish Journal of Management Studies, 23(2), 57-71. DOI: 10.17512/pjms.2021.23.2.04

20. Civelek, M., Ključnikov, A., Fialova, V., Folvarčná, A., \& Stoch, M. (2021b). How innovativeness of family-owned SMEs differ depending on their characteristics? Equilibrium. Quarterly Journal of Economics and Economic Policy, 16(2), 413-428. doi: 10.24136/eq.2021.015

21. Civelek, M., Ključnikov, A., Fialova, V., Folvarčná, A., \& Stoch, M. (2021c). Major obstacles in innovative activities of family-owned SMEs: Evidence from Czechia. Economics and Sociology, 14(2), 137-149. doi:10.14254/2071-789X.2021/14-2/7

22. Collins, D., \& Tisdell, C. (2002). Age-related lifecycles: Purpose variations. Annals of Tourism Research, 29(3), 801-818.

23. Crang, M. (1997). Picturing practices: Research through the tourist gaze. Progress in human geography, 21(3), 359-373.

24. Crompton, J. L. (1979). Motivations for pleasure vacation. Annals of tourism research, 6(4), 408-424.

25. Cucculelli, M., \& Goffi, G. (2016). Does sustainability enhance tourism destination competitiveness? Evidence from Italian Destinations of Excellence. Journal of Cleaner Production, 111, 370-382

26. Dai, H. D. (2005). Transformation of Islamic political identity in Turkey: Rethinking the West and Westernization. Turkish studies, 6(1), 21-37 


\section{JOURNAL OF TOURISM AND SERVICES}

Issue 23, volume 12, ISSN 1804-5650 (Online)

www.jots.cz

27. Dawadi, B. R., \&Upadhayaya, P. K. (2013). Role of tourism in urban-rural integration: Reflexions from trekking (adventure) tourisme in Pokhara. BR Upreti, PK Upadhayaya\& T. Sapkota edts, Tourism in Pokhara. Issues, Trends and Future Prospects for Peace and Prosperity, 251-287.

28. De Clercq, D., \& Voronov, M. (2009). Toward a practice perspective of entrepreneurship: Entrepreneurial legitimacy as habitus. International small business journal, 27 (4), 395-419.

29. Devkota, N., Paudel, U. R., \& Bhandari, U. (2020a). Tourism entrepreneurs' expectation from the provincial government in touristic city-Pokhara, Nepal. Journal of Hospitality and Tourism Insights, 3(3), 329-351.

30. Devkota, N., Paudel, U. R., \& Bhandari, U. (2020b). Does westernization influence the business culture of a touristic city? Economics \& Sociology, 13(4), 154-172.

31. Devkota, N., Paudel, U. R., \& Bhandari, U. (2021). Conveying impetus for fostering tourism and hospitality entrepreneurship in touristic destination: Lessons learnt from Pokhara, Nepal. The Gaze: Journal of Tourism and Hospitality, 12(1), 88-111.

32. Doğan, H. Z. (1989). Forms of adjustment: Socio-cultural impacts of tourism. Annals of Tourism Research, 16(2), 216-236.

33. Domi, S., Keco, R., Capelleras, J.-L., \& Mehmeti, G. (2019). Effects of innovativeness and innovation behavior on tourism SMEs performance: The case of Albania. Economics and Sociology, 12(3), 67-85.

34. Enato, L. S. E. (2018) African value system and the impact of westernization: A critical evaluation of Esan Society in Edo State, Nigeria. African journal of history and archaeology, 3(1), 10-26.

35. Endy, C. (1998). Travel and world power: Americans in Europe, 1890-1917. Diplomatic History, 22(4), 565-594.

36. Eric Amuquandoh, F., \& Asafo-Adjei, R. (2013). Traditional food preferences of tourists in Ghana. British Food Journal, 115(7), 987-1002.

37. Franklin, A., \& Crang, M. (2001). The trouble with tourism and travel theory?. Tourist Studies, 1(1), 6.

38. Gantait, A., Mohanty, P., Singh, K., \& Sinha, R. (2021). Pro-poor tourism in India: Reality or hyperbole!. Psychology and Education, 58(2), 9672-9682.

39. Garland, B. R., \& West, S. J. (1985). The social impact of tourism in New Zealand. Massey Journal of Asian \& Pacific Business, 1(1), 34-39.

40. Gavurova, B., Privara, A., Janikova, J., \& Kovac, V. (2021). Quantification of Tourism Sector Parameters Related to Competitiveness of Countries According to Macroeconomic Indicators. Journal of Competitiveness, 13(3), 56-72. https://doi.org/10.7441/joc.2021.03.04

41. Gee, C., \&Fayos-Sola, E. (1997). Travel distribution systems. In Conference Proceeding of International Tourism: A Global Perspective. Madrid, Spain, the World Tourism Organisation (pp. 95-116).

42. Ghanem, J. (2017). Conceptualizing "the Tourist": A critical review of UNWTO definition. Universitat de Girona, 1-39.

43. Goffi, G., Osti, L., Nava, C. R., Maurer, O., \& Pencarelli, T. (2020). Is preservation the key to quality and tourists' satisfaction? Evidence from Lake Garda. Tourism Recreation Research, 1-7.

44. Grilli, G., Tyllianakis, E., Luisetti, T., Ferrini, S., \& Turner, R. K. (2021). Prospective tourist preferences for sustainable tourism development in small island developing states. Tourism Management, 82, 104178. 


\section{JOURNAL OF TOURISM AND SERVICES}

Issue 23, volume 12, ISSN 1804-5650 (Online)

www.jots.cz

45. Hadwen, W. L., Arthington, A. H., Boon, P. I., Taylor, B., \& Fellows, C. S. (2011). Do climatic or institutional factors drive seasonal patterns of tourism visitation to protected areas across diverse climate zones in eastern Australia?. Tourism Geographies, 13(2), 187-208

46. Herold, E., Garcia, R., \&DeMoya, T. (2001). Female tourists and beach boys: Romance or sex tourism?. Annals of tourism Research, 28(4), 978-997

47. Hsu, T. K., Tsai, Y. F., \& Wu, H. H. (2009). The preference analysis for tourist choice of destination: A case study of Taiwan. Tourism management, 30(2), 288-297

48. Hung, K., Yang, X., Wassler, P., Wang, D., Lin, P., \& Liu, Z. (2017). Contesting the commercialization and sanctity of religious tourism in the shaolin monastery, China. International Journal of Tourism Research, 19(2), 145-159

49. Iglesias-Sánchez, P. P., Correia, M. B., Jambrino-Maldonado, C., \& de las Heras-Pedrosa, C. (2020). Instagram as a co-creation space for tourist destination image-building: Algarve and Costa del Sol case studies. Sustainability, 12(7), 2793.

50. Irandu, E. M. (2004). The role of tourism in the conservation of cultural heritage in Kenya. Asia Pacific journal of tourism research, 9(2), 133-150.

51. Jóhannesson, G. T. (2005). Tourism translations: Actor-network theory and tourism research. Tourist Studies, 5(2), 133-150.

52. Jóhannesson, G. T., Ren, C. B., van der Duim, R., \& Munk, A. K. (2014). Actor-network theory and tourism research: Approaches, implications and future opportunities. In Tourism methodologies (pp. 119-136), Copenhagen Business School Press.

53. Jönsson, C., \& Devonish, D. (2008). Does nationality, gender, and age affect travel motivation? A case of visitors to the Caribbean island of Barbados. Journal of Travel \& Tourism Marketing, 25(3-4), 398-408.

54. Ključnikov, A., Civelek, M., Čech, P. \& Kloudová, J. (2019). Entrepreneurial orientation of SMEs' executives in the comparative perspective for Czechia and Turkey. Oeconomia Copernicana, 10(4), 773-795. doi: 10.24136/oc.2019.035

55. Ključnikov, A., Civelek, M., Krajčík, V. \& Ondrejmišková, I. (2020a). Innovative Regional Development of the Structurally Disadvantaged Industrial Region by the Means of the Local Currency. Acta Montanistica Slovaca, $25 \quad$ (2), 224-235. DOI:https://doi.org/10.46544/AMS.v25i2.9

56. Ključnikov, A., Civelek, M., Polách, J., Mikoláš, Z., \& Banot, M. (2020b). How do security and benefits instill trustworthiness of a digital local currency? Oeconomia Copernicana, 11(3), 433-465. doi: 10.24136/oc.2020.018

57. Ključnikov, A., Civelek, M., Vozňáková, I., \& Krajčík, V. (2020c). Can discounts expand local and digital currency awareness of individuals depending on their characteristics? Oeconomia Copernicana, 11(2), 239-266. doi: 10.24136/oc.2020.010

58. Ključnikov, A., Civelek, M., Fialova, V., \& Folvarčná, A. (2021). Organizational, local, and global innovativeness of family-owned SMEs depending on firm-individual level characteristics: evidence from the Czech Republic. Equilibrium. Quarterly Journal of Economics and Economic Policy, 16(1), 169-184. doi: 10.24136/eq.2021.006

59. Kozak, M., \& Martin, D. (2012). Tourism life cycle and sustainability analysis: Profit-focused strategies for mature destinations. Tourism Management, 33(1), 188-194.

60. Kumaravadivelu, B. (2008). Cultural globalization and language education. Yale University Press.

61. Lamers, M., Van der Duim, R., \& Spaargaren, G. (2017). The relevance of practice theories for tourism research. Annals of Tourism Research, 62, 54-63.

62. Law, J. (1999). After ANT: complexity, naming and topology. The Sociological Review, 47(S1), 1-14. 


\section{JOURNAL OF TOURISM AND SERVICES}

Issue 23, volume 12, ISSN 1804-5650 (Online)

www.jots.cz

63. Law, R., Leung, R., Lo, A., Leung, D., \& Fong, L. H. N. (2015). Distribution channel in hospitality and tourism: Revisiting disintermediation from the perspectives of hotels and travel agencies. International Journal of Contemporary Hospitality Management, 27(3), 431452.

64. Laws, E. (1998). Conceptualizing visitor satisfaction management in heritage settings: an exploratory blueprinting analysis of Leeds Castle, Kent. Tourism Management, 19(6), 545554.

65. Liao, C. S., \& Chuang, H. K. (2020). Tourist preferences for package tour attributes in tourism destination design and development. Journal of Vacation Marketing, 26(2), 230-246.

66. Light, D. (2001). 'Facing the future': Tourism and identity-building in post-socialist Romania. Political geography, 20(8), 1053-1074.

67. Mira, MRC, Moura, AFA, Mónico, LDS (2018). A new measure of the quality of tourism product. Journal of Tourism and Services, 9 (17), 1-22.

68. MOCTCA (2019). Nepal Tourism Statistics, 2018. Retrieved from https://www.tourism.gov.np/files/NOTICE\%20MANAGER_FILES/Nepal_\%20tourism_sta tics_2019.pdf

69. Moscardo, G. (1996). Mindful visitors: Heritage and tourism. Annals of tourism research, 23(2), 376-397

70. Mowforth, M., \& Munt, I. (1998). Tourism and sustainability: New tourism in the third world, Routledge.

71. Mura, L., \& Kajzar, P. (2019). Small businesses in cultural tourism in a Central European country. Journal of Tourism and Services, 10(19), 40-54.

72. Navickas, V., Petroké, I., Bačiulienè, V., (2021). Impact of free economic zones on regional economic development: the case of Klaipeda free economic zone in Lithuania. International Journal of Entrepreneurial Knowledge, 9(1), 97-111.

73. Nepal, S. K. (2000). Tourism in protected areas: The Nepalese himalaya. Annals of Tourism Research, 27(3), 661-681.

74. Nepal, S. K. (2020). Adventure travel and tourism after COVID-19-business as usual or opportunity to reset?. Tourism Geographies, 22(3), 646-650.

75. Nettekoven, L. (1979). Mechanisms of intercultural interaction (pp. 135-145). Oxford University Press for World Bank and UNESCO.

76. Nicolaides, A. (2015). Tourism stakeholder theory in practice: Instrumental business grounds, fundamental normative demands or a descriptive application?. African Journal of Hospitality, Tourism and Leisure, 4 (2), 1-27.

77. Nuryanti, W. (1996). Heritage and postmodern tourism. Annals of tourism research, 23(2), 249-260.

78. Nyaupane, G. P., Morais, D. B., \& Dowler, L. (2006). The role of community involvement and number/type of visitors on tourism impacts: A controlled comparison of Annapurna, Nepal and Northwest Yunnan, China. Tourism management, 27(6), 1373-1385

79. Otoo, F. E., Kim, S., \& Choi, Y. (2020). Understanding senior tourists' preferences and characteristics based on their overseas travel motivation clusters. Journal of Travel \& Tourism Marketing, 37(2), 246-257.

80. Paudel, U. R., \& Devkota, N. (2018). Socio-economic influences on small business performance in Nepal-India open border: Evidence from cross-sectional analysis. Economics \& Sociology, 11(4), 11-30.

81. Paudel, U. R., Devkota, N., \& Bhandari, U. (2018). Socio-cultural and economic factors in cross-border purchase: A study of customers' perspective in Sunauli-Nepal/India Border. Modern Economy, 9(6), 1089-1102. 


\section{JOURNAL OF TOURISM AND SERVICES}

Issue 23, volume 12, ISSN 1804-5650 (Online)

www.jots.cz

82. Pearce, D. G., \& Schänzel, H. A. (2015). Destinations: tourists' perspectives from New Zealand. International Journal of Tourism Research, 17(1), 4-12.

83. Pearce, P. L. (2013). The social psychology of tourist behaviour: International series in experimental social psychology (Vol. 3). Elsevier.

84. Peric, V. (2005, November). Tourism and globalization. In Proceedings of the 6th International Conference of the Faculty of Management Koper (pp. 24-26).

85. Pieterse, J. N. (2010). Development theory. Sage.

86. Poria, Y., Butler, R., \& Airey, D. (2004). Links between tourists, heritage, and reasons for visiting heritage sites. Journal of Travel Research, 43(1), 19-28.

87. Rai, R. K., Neupane, K. R., Bajracharya, R. M., Dahal, N., Shrestha, S. and Devkota, K. (2019). Economics of climate adaptive water management practices in Nepal. Heliyon, 5(5), 1-7.

88. Ranasinghe, R. (2014). The perceived impacts of tourism on the small scale entrepreneurs (case of world heritage city Dambulla, Sri Lanka). International Journal of Scientific and Research Publications, 4(10), 1.

89. Sati, V. P. (2021). Out-migration in uttarakhand himalaya: Its types, reasons, and consequences. Migration Letters, 18(3), 281-295.

90. Scholte, J. A. (2005). Globalization: A critical introduction. Macmillan International Higher Education.

91. Sharma (2017, February). 50 years of Nepali tourism. New Business Age (Cover story). Retrived from https://newbusinessage.com/MagazineArticles/view/1706.

92. Sharma, Pitambar (2012) in Sharma SR, Upreti BR and Pyakuryal K (eds.) (2012). Nepal 2030: A Vision for Peaceful and Prosperous Nation. Kathmandu: South Asia Regional Coordination Office of the Swiss National Centre of Competence in Research (NCCR NorthSouth) and Department of Development Studies, Kathmandu University

93. Stevens, S. (1988). Tourism and development in Nepal. Kroeber Anthropological Society Papers, 67 (68), 67-80.

94. Stringer, P. F. (1981). Hosts and guests the bed-and-breakfast phenomenon. Annals of Tourism Research, 8(3), 357-376.

95. Su, Q., Cao, Y. H., \& Lin, B. Y. (2005). Comparative study on residents' perception of tourism impact at tourist places. Chinese Geographical Science, 15(1), 70-79.

96. Tan, S. K., Tan, S. H., Luh, D. B., \& Kung, S. F. (2016). Understanding tourist perspectives in creative tourism. Current Issues in Tourism, 19(10), 981-987.

97. Tong, H. K., \& Cheung, L. H. (2011). Cultural identity and language: A proposed framework for cultural globalisation and glocalisation. Journal of Multilingual and Multicultural Development, 32(1), 55-69.

98. Upreti, B. R., \& Upadhyaya, P. K. (2013). Tourism in Pokhara: Nepal's pride and means for peace and prosperity. Tourism In Pokhara: Issues, Trends and Future Prospects for Peace and Prosperity, Pokhara Tourism Council, Pokhara, 1-25.

99. Urry, J. (1992). The tourist gaze "revisited". American Behavioral Scientist, 36(2), 172-186.

100. Uslu, A., Alagöz, G., \& Güneş, E. (2020). Socio-cultural, economic, and environmental effects of tourism from the point of view of the local community. Journal of Tourism and Services, 11(21), 1-21.

101. Van der Duim, R., Ren, C., \&ThórJóhannesson, G. (2013). Ordering, materiality, and multiplicity: Enacting actor-network theory in tourism. Tourist Studies, 13(1), 3-20.

102. Vavrecka, V., Zauskova, A., Privara, A., Civelek, M., Gajdka, K (2021). The Propensity of SMEs Regarding the Usage of Technology Enabled Marketing Channels: 


\section{JOURNAL OF TOURISM AND SERVICES}

Issue 23, volume 12, ISSN 1804-5650 (Online)

www.jots.cz

Evidence from the Czech, Slovak and Hungarian SMEs. Transformations in Business \& Economics, 20(2-53), 223-240.

103. Van der Schyff, T., Meyer, D., \& Ferreira, L. (2019). Analysis of the impact of tourism sector as a viable response to South Africa's growth and development challenges. Journal of International Studies, 12(1), 168-183.

104. Walker, S., Valaoras, G., Gurung, D., \& Godde, P. (2001). Women and mountain tourism: Redefining the boundaries of policy and practice. Women as producers and consumers of tourism in developing regions, 167-190.

105. Wilson, E., \& Little, D. E. (2008). The solo female travel experience: Exploring the 'geography of women's fear'. Current Issues in Tourism, 11(2), 167-186.

106. Wood, R. E. (1980). International tourism and cultural change in Southeast Asia. Economic Development and Cultural Change, 28(3), 561-581.

107. World Heritage Encyclopedia (2019). Pokhara, World Heritage Encyclopedia (Article id: WHEBN0001037033). Retrieved from http://www.worldlibrary.org/articles/pokhara

108. Yuan, S., \& McDonald, C. (1990). Motivational determinates of international pleasure time. Journal of Travel Research, 29(1), 42-44.

109. Zhang, M., Quanxin, S. U. N., Jinchuan, C. H. E. N., \& Jifu, G. U. O. (2008). Travel behavior analysis of the females in Beijing. Journal of Transportation Systems Engineering and Information Technology, 8(2), 19-26.

\section{Brief description of Authors:}

\section{Niranjan Devkota, PhD}

ORCID ID: https://orcid.org/0000-0001-9989-0397

Affiliation: Research Management Cell, Quest International College, Pokhara University, Gwarko, Lalitpur, Nepal. https:/ quest.edu.np/quest-research-management-cell-quest-rmc/

Email: niranjandevkota@gmail.com

Dr. Devkota is an economist with the special focus behavioral economics linking agriculture, climate change, tourism and other contemporary issues over a decade. He is now working as coordinator of Research Management Cell at Quest International College affiliated to Pokhara University, Nepal. His research is focused on perception and behavioral studies for people. He has presented his research ideas in different conferences/seminars and workshops. He has published in various journals and performed as reviewer for several journals. He is also engaged in various development projects.

\section{Udaya Raj Paudel}

ORCID ID: https://orcid.org/0000-0002-5234-5081

Affiliation: Principal, Quest International College, Pokhara University, Gwarko, Lalitpur, Nepal. https://quest.edu.np/team/udaya-raj-paudel/

Mr. Paudel is a PhD scholar in TU, Kathmandu, Nepal- working in the field of communication. His research works reflect communication, ethics, business and culture with latest practices worldwide. More than two decades of educational institution management and teaching English and Communication has propelled him as communication consultant in various organizations. Mr. Paudel projects commitments in research and ethical communication and consumption. He has presented his research ideas in different conferences/seminars and workshops. He has published in various journals and performed as reviewer for several journals.

Ing. Iveta Hamarneh, Ph.D. 


\section{JOURNAL OF TOURISM AND SERVICES}

Issue 23, volume 12, ISSN 1804-5650 (Online)

www.jots.cz

ORCID ID: https://orcid.org/0000-0002-4724-098X

Affiliation: Department of Tourism, University of Business in Prague, Spálená 76/14, Prague 1, Czech Republic, www.vso.cz.

Email: hamarneh@vso-praha.eu

Iveta Hamarneh is a Vice-Rector for Study at the University of Business in Prague and a member of the Department of Tourism. She has much experience in the teaching of courses regarding tourism. She is actively involved in the promotion of the tourism sector in the Czech Republic through membership in the Czech Travel Press, Society of Scientific Experts in Tourism, Association for Tourism and Leisure Education and Research, and European Regions for Competitive and Sustainable Tourism. She is attending and organizing the tourism conferences.

\section{Udbodh Bhandari}

ORCID ID: https://orcid.org/0000-0002-4881-667X

Affiliation: Department of Sociology, Quest International College, Pokhara University, Gwarko, Lalitpur, Nepal.

Email: aruudbodh@gmail.com

Mr. Bhandari is a sociologist and a lecturer of sociology/anthropology in colleges of Nepal. His research is focused on social, behavioral, culture aspects of tourism and other sectors. Having academic teaching experience of more than decade he is also involved in various development projects. Beside that, he have also presented various research ideas in workshops, seminars and conferences. He has also published in various journals and serve as reviewer to some journals as well. 